\title{
TVET Qualification Statuses in Sri Lankan Labour Market
}

\author{
H.M.A.D.K Herath ${ }^{1}$, Prof. Dayantha S Wijayasekara ${ }^{2}$, Dr. N.N.J Nawarathna ${ }^{3}$ \\ ${ }^{1}$ Assistant Director, Tertiary and Vocational Education Commission, Colombo, Sri Lanka \\ ${ }^{2}$ Pofessor, Chancellor, University of Vocational Technology, Colombo, Sri Lanka
}

${ }^{3}$ Head of the Department of Human Resources Management, University of Colombo, Colombo, Sri Lanka

\begin{abstract}
The purpose of this paper is to investigate to TVET qualification holder's statuses in the labour market according to the expected factors and examine their expectations. The research conduct mix of qualitative and quantitative approaches to identify the research gap with using documents analysis with their job statuses to the labour market needs for TVET pass outs. In this research, expose labour market perspective to the outcome based of the TVET sector courses and illustrative competencies relevant to the occupations. TVET qualifications comprises skills in TVET qualification comes to labour market enter as engineers, technicians and skill works.
\end{abstract}

Keywords: Competencies, Expectation, Labour Market, Qualification, Statuses, Skill

\section{Introduction}

TVET qualification in Sri Lanka, come from the labour market with different qualification status significance to the different occupations. Currently, in Sri Lanka government and non-government institutions conduct various courses with various duration, mode, and levels in TVET sector. TVET sector output directly goes to the labour market and that courses contain the qualifications in the sectors carried different identifications and only part of them are certified with NVQ. In labour market, TVET sector pass outs to industry they are enrolled to job with their qualification level, but the industry persons are with the misperception to the indicated qualification with require occupational competencies, which is required. Therefore, this study investigates how to identify the different qualifications predict occupations in the labour market, and resolved with a proposing conceptual model by considering the labour market aspects with qualifications which is important to industries to identified placement the job with the suitable TVET pass outs.

In Sri Lanka tertiary level education gets highest priority when socio economically evaluating the whole education system of the country, where TVET sector plays a major role. TVET system should emphasis on demand driven vocational education and training through an intensive relation with the labour market (Meer, 2007), it is essential that TVET sector consist of features that are different from the general education, as it includes the studying of technologies with related sciences, gaining of practical skills, attitudes, understanding and knowledge (Saud, Shu'aibu, Yahaya and Yasin,2011) relating to occupations, in order to cater requirement of various sectors of occupations directing to occupation with fulfilment of knowledge, skill and attitude with regards to employment. In that scenario TVET sector's outcomes must be organized with identifying the labour market policies, monitoring, career guidance, employment policies and other labour market activities to increase the efficiency of the system
(Castany, 2010). Occupational competencies build up in education and training for the expectation fulfilment in labour market.

Main objective of this research would be to identify a proper mechanism to map the labour market requirements with competencies and skills of TVET pass outs. Sri Lanka labour market require investing in building job specific technical and vocational skills to increase competitiveness in TVET (Chandrasiri\& Gunatilake, 2015). In order to do that react on the labour market value of different types of educational paths in general and on the comparison of educational paths in specific manner (Tuor, Backes-Gellner, 2010). Considering competencies of the non-degree, courses in Sri Lanka various number of diploma courses are available to follow which are identified with various names and identifications. Considering the present situation there is no criteria or a system specifically for labour market to capture their needs. These courses need to be mapped against the well-defined NVQ framework and assigned required NVQ levels based on their output.

\section{Research Objective}

This paper is work for specific objective as follows:

1) To determine career competencies necessary for different qualifications in TVET programs to be used by both providers and industry

\section{Conceptual Framework}

Stakeholders of the TVET sector represent industry persons, institutes, academics and students consider as included in NVQ operation manual used to this proposed conceptual framework to fulfil research objectives. This used the independent variable as the Institution factors, Monitoring factors to find out the effect of the labour market expectation with the mediating on TVET qualification status included in framework and represent constructed with the perspective of the labour market. The conceptual framework strengthens

\section{Volume 6 Issue 12, December 2017}




\section{International Journal of Science and Research (IJSR) \\ ISSN (Online): 2319-7064 \\ Index Copernicus Value (2016): 79.57 | Impact Factor (2015): 6.391}

with three selected theories of Human Capital Theory, Career Construction Theory and Theory of Work Adjustment are linking theories to come up the findings through the objectives of the research.

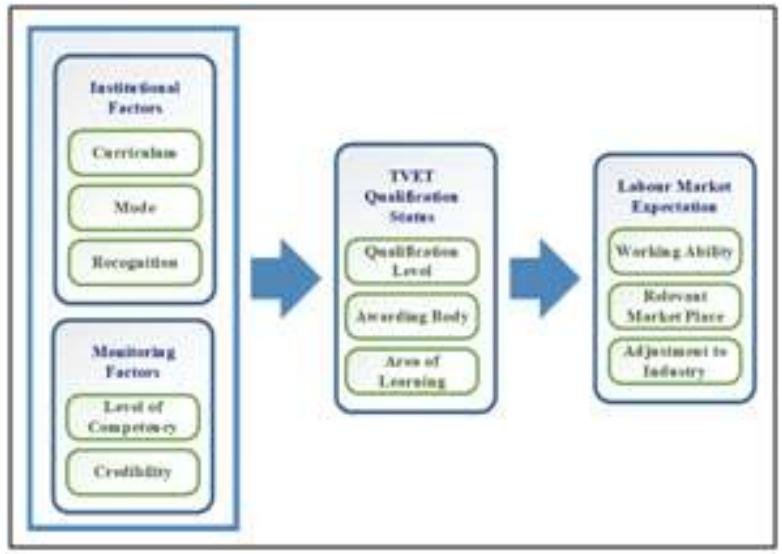

Figure 1: Conceptual Framework

\section{Methodology}

Current study used the available survey data to classify present labour market and giving overall view of labour market with model. In this study clarifying the objectives with observing the respondents from labour market viewpoint of the TVET programs to job-related skills and competencies for the human resource development. In order to research conduct structured interview with TVET pass out and student as well as the training provides in final stage for finalizing the model following documentary survey collect the data by analysing NCS, Curriculum by conducting the workshop with the relevant stakeholders in the selected occupation sector.

TVET Qualification collaboration of education, training and works as follows.

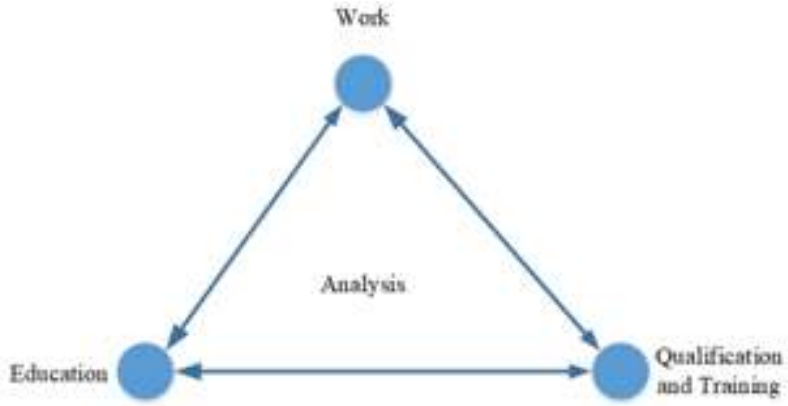

Figure 2: The interaction of education, training and work Source: (Rauner, 2009)

This study using the interaction of education, training and work find out through the objectives with the competencies and skills relevance to the TVET courses to TVET labour market expectations.

\section{Results and findings}

In this paper considered supervisory, Managerial and craftsmen level workers skills percentages discussed sectors of construction, hospitality, ICT and light engineering

\section{a) Supervisory Level}

Considering the labour market skills among sectors of construction, hospitality, ICT and light engineering sectors difference level of percentages required in skill categories. As figure 3 shows, ICT sector is required more skills and its followed by hospitality then construction and finally light engineering sectors.

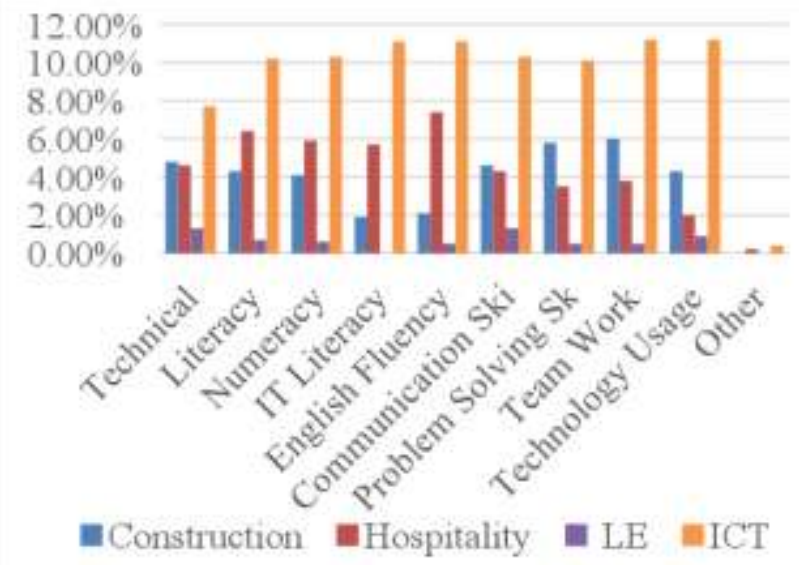

Figure 3: Supervisory level by sector skills requirements

\section{b) Managerial Level}

Considering the labour market in managerial level consist of skills among sectors of construction, hospitality, ICT and light engineering sectors difference level of percentages required in categories analysis as follows.

Considering the managerial level sills requirement than other supervisory and craftsmen degree of change is lowers and same structure or the skills needed is same among most of the workers in managerial in selected sectors, but the ratios are varying upon the sector requirement in labour market

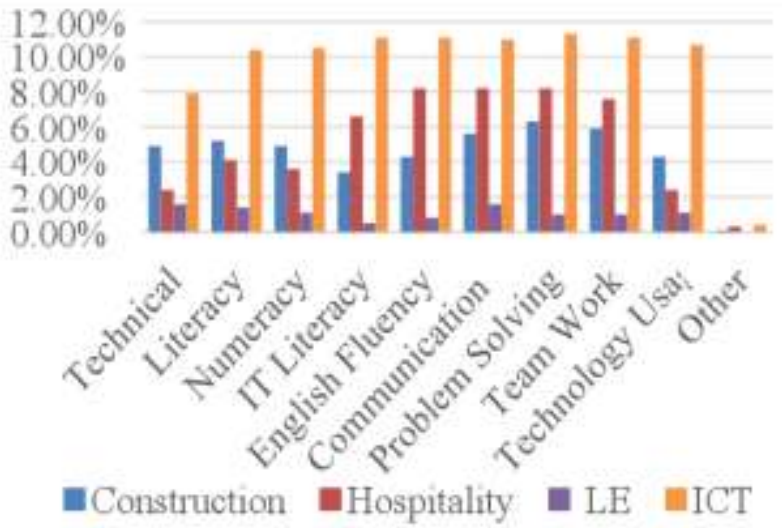

Figure 4: Managerial level by sector skills requirements

\section{c) Craftsmen Level}

Considering the labour market in craftsmen level consist of skills among sectors of construction, hospitality, ICT and light engineering sectors difference level of percentages required in categories analysis as follows. 


\section{International Journal of Science and Research (IJSR) \\ ISSN (Online): 2319-7064}

Index Copernicus Value (2016): 79.57 | Impact Factor (2015): 6.391

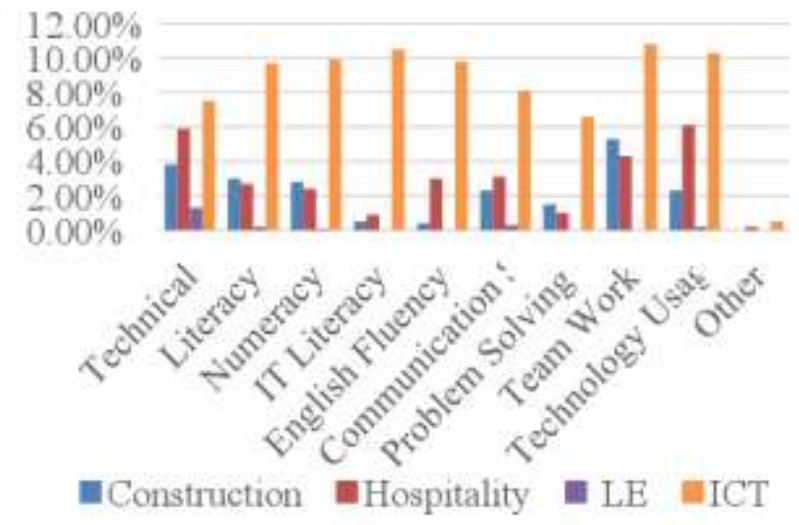

Figure 5: Craftsmen level by sector skills requirements

As shown in figure craftsmen level skills needed in labour market more importance going to technical, Technological and team working among the selected sector skills requirements.

\section{Recommendation}

The study found that TVET pass outs skills regarding to employability or come to the labour market matched to the requirement in labour market expectations. The current study shows that, after training programs completion TVET pass outs found employment mismatches with the labour market needs that is highly effective on human resources development. So, there should be a plan for every industry sector identifying cluster of skills ratios. There is a mismatch in the TVET supply and the skilled labour in various demanded occupation categories of employment labour market structure fulfilling. Achieve the labour market essential to conduct courses in TVET sector with varieties in the market demand to increase the output for most demanded industrial categories. A non-existence of qualified according to market requirement through the labour force has made it demanding for the training institutes to decide potential students for each training course requires. And also, necessary to training programmes should be contest their training according to the potential demand.

\section{Conclusion}

This study finding among the qualification status carry out to the labour market to identify and also the matching competencies/ skills with the relevant occupation in TVET sector. The study mainly concentrating to developing linkages among TVET qualification follows demand driven qualification to sector. In order to its follows the first stage with the analysis the labour market expectation for the occupations categories in that so research used the secondary data set sever data, which collected in the parallel period. The skills requirement concerning the fulfilling expectations of the labour carry out study to skills requirement for the Engineers, Technicians and skill works in the labour market expectation to the Managerial level, Supervisory Level and Craftsmen Level. As per the data analysis, shows in the table required skills percentages are different from the sector to sector and the level of the occupation categories. The study used the present data set in TVEC data base including NVQ certification and registration and accreditation TVEC register institute.

The supply side data analysis finds the factors affecting to differences among the qualification status according to the awarding body, crediting, relevant sector and also the level of the qualification. That supply side competency levels category discussed and analyse according to the documentation analysis and giving weightages to particular competency consist with categories in level of competency. That is must to be the link the requirement arises through the labour market expected among the occupation categories such as skills works, managerial and supervisory level align according to the fulfilling the labour market expectation.

\section{References}

[1] Castany, L., 2010. The role of size in firms' training: evidence from Spain. International Journal of Manpower, 31(5), pp.563-84.

[2] Chandrasiri, S. \& Gunatilaka, R., 2015. The skills gap in four industrial sectors in Sri Lanka. Colombo: ILO Country Office for Sri Lanka and the Maldives. Available at:

http://www.skillsforemployment.org/wcmstest4/idcplg?I dcService=GET_FILE $\&$ dID $=198977 \&$ dDocName $=$ WC MSTEST4_138855\&allowInterrupt=1.

[3] Meer, J., 2007. Evidence on the returns to secondary vocational education. Economics of Education Review, 26(5), pp.559-73.

[4] Rauner, F., 2009. Qualifications Research. In R. Maclean, D. Wilson \& C. Chinien, eds. International Handook of Eductiaon for the Changing World of Work: Bridging Academic and Vocational Learning. Springer Science \& Business Media. pp.1553-61.

[5] Saud, M.S., Shu'aibu, B., Yahaya, N. \& Yasin, A.-M., 2011. Effective integration of information and communication technologies (ICTs) in technical and vocational education and training (TVET) toward knowledge management in the changing world of work. African Journal of Business Management, 5(16), pp.6668-73.

[6] Tour, S.N. \& Backes-Gellner, U., 2010. Risk-return trade-offs to different educational paths: vocational, academic and mixed. International Journal of Manpower, 31(5), pp.495-519.

\section{Author Profile}

H.M.A.D.K Herath, Assistant Director, Tertiary and Vocational Education Commission, Sri Lanka.

Prof. Dayantha S Wijayasekara, Chancellor, University of Vocational Technology, Sri Lanka.

Dr. N.N.J Nawarathna, Head of the Department of Human Resources Management, University of Colombo, Sri Lanka.

\section{Volume 6 Issue 12, December 2017}

